\title{
Massage and Its Effect on Some Health Conditions
}

\author{
Elizabeta Popova Ramova*, Hristina Stojanovska, Vesna Sofronijevska and Biljana Angelovska \\ Training implementation center-Bitola, Southeast Europe
}

*Corresponding author: Elizabeta Popova Ramova, Training implementation

Received Date: March 18, 2019

center-Bitola, R. Macedonia Balkan Peninsula, Southeast Europe.

Published Date: April 18, 2019

\begin{abstract}
The massage is the first therapy that every child comes in contact after its born, every mammal after its born. We see on massage from medical science on its effect by many illnesses on cellular level. The aim of our research is to make one rewire for therapy effect of massage by some illnesses, and prove it, by medical assessment tools.
\end{abstract}

Material and method: We have made one investigation on medical data bases, to resolve all our knowledge and compare with other researchers world way for therapy effect of massage.

Results: We have represented our research in three parts: effect of aromatherapy, application of massage by some illnesses and side effects from massage.

Discussion: Many researchers proved the therapy effect of some traditional form of massage and medical massage too. It is accept from Association of Physical medicine doctors of Europe, like a therapy modality.

Conclusion: Massage has many positive health effects, but medical staff and massage practioners must be careful and to expect some complications specially in area of osteoporotic bones and vessels.

Keywords: Massage; Physical medicine modality; Effects

\section{Introduction}

The massage is the first therapy that every child comes in contact after its born, every mammal after its born. It is the first touch from the mother that mimics and conveys positive energy [1]. Viewed from today's distance, during the study for the effects of the massage as a therapy, when we get the information we formed the mosaic called massage. We see on massage from medical science on its effect by many illnesses on cellular level[2,3].The word massage comes from the Latin word "massare", which means grunting or from the Arabic word "mas" meaning pressing. It is found in the literature for the first time in 1813 used in France by Lepage [4]. The massage exists from time immemorial. Man is instinctively rubbing in pain and swelling throughout the body, which is likely to have been used for treatment since ancient times. Massage data as a treatment for the first time meets 3000 years ago. BC, and was carried out in ancient Asian cultures in India and China [5,6].

The massage was used by the Egyptians, the Assyrians, the Persians, and the ancient Greeks and Romans as a method of treating diseased and injured parts of the body. Famous doctors
Hippocrates and Galen recommended it as a way of treatment [7]. The first entries for a sports massage date from the Roman period, and modern medicine is thought to have been introduced by the Swedes Per Henrik Ling in the 18th century. The names of Mason A., Johann Metzger, Von Mosengeil, etc. are related to the massage. The popularity of massage in different cultures during the millennia has been increasing and decreasing.

During the Renaissance, medical scientists renewed the massage and tried to understand the physiology and anatomy influenced by this method. The French medical community supported the "friction of the skin - and allowed many different massage techniques" [8]. Many of the terms for these techniques, such as effleurage, petrissage, tapotement and friction massage, are used today in English medical terminology.

The popularity of massage as a therapeutic intervention has changed considerably, even over the past few decades. This change took place due to the influence of medical professionals, who believed that medications and surgical procedures needed to 
reduce disease and suffering. But in recent years there has been a renewed interest in massage, which has led to scientific research on its use as a therapeutic method [9].

As time went on, as we grew up as applicators in the field of Physical Therapy and Rehabilitation, our understanding for the specific possibilities of the massage for different patient's disease and the human's difficulties also grew. After more than 20 years, also we have personal experiences. It was difficult for us to get good literature, but today with the possibilities of electronic communication we can check whether our knowledge has been noted by other massage practitioners around the world. This study is dedicated to all supporters of physical therapy and rehabilitation that our experiences can check in their patients, as we have shared with many, around the world [10].

The aim of our research is to make one rewire for therapy effect of massage by some illnesses, and prove it, by medical assessment tools.

\section{Material and Method}

We have made one investigation on medical data bases, to resolve all our knowledge and compare with other researchers world way for therapy effect of massage. Its effect was analyzed during centuries, from records in medical books. The key words of our investigations were massage, history of application, application by some illness, and proved effect with medical scale or measurable parameters. We have analyzed 38 ill conditions, side effects of massage and aroma massage like a combination of two therapy effects. From all our research we have consulted 505 publications. It is published in March 2018, like a Guide book with educational purpose for doctors, physiotherapists, nurses and masseurs. We shall represent it by disease, area of application of massage and proved medical effect.

\section{Results}

We represent our results in follow tables:

Table 1: Effect of aroma massage on some illnesses.

\begin{tabular}{|c|c|c|}
\hline Illness & $\begin{array}{l}\text { Application Like } \\
\text { Massage with Oil } \\
\text { From }\end{array}$ & Effect \\
\hline $\begin{array}{c}\text { Muscles skeletal } \\
\text { pain [11] }\end{array}$ & $\begin{array}{l}\text { Lavender, } \\
\text { Eucalyptus, Mint, } \\
\text { Rosemary, }\end{array}$ & $\begin{array}{c}\text { Decrease the pain, } \\
\text { measured by VAS or NAS } \\
\text { scale, increase mobility }\end{array}$ \\
\hline $\begin{array}{c}\text { Rheumatology, } \\
\text { Arthritis, [12] Knee } \\
\text { arthritis, }\end{array}$ & & $\begin{array}{c}\text { Decrease the pain, } \\
\text { measured by VAS or NAS } \\
\text { scale, increase mobility }\end{array}$ \\
\hline Fibromyalgia [13] & $\begin{array}{l}\text { Chamomile, Rose, } \\
\text { Lavender, Rosemary, }\end{array}$ & $\begin{array}{c}\text { Decrease the pain, } \\
\text { measured by VAS or NAS } \\
\text { scale, increase mobility }\end{array}$ \\
\hline $\begin{array}{c}\text { Anxiety, Personality } \\
\text { disorders [14] }\end{array}$ & Lavender & Decrease anxiety \\
\hline Depression [15] & $\begin{array}{l}\text { Lavender, cedar, } \\
\text { Chamomile, }\end{array}$ & Increase mood \\
\hline Stress [16] & $\begin{array}{l}\text { Lemon oil, Orange } \\
\text { oil, Bergamot, } \\
\text { Sandal, }\end{array}$ & Decrease anxiety \\
\hline $\begin{array}{c}\text { Alzheimer disease } \\
{[17]}\end{array}$ & $\begin{array}{c}\text { Ginger, Mirth, } \\
\text { Orange, Eucalyptus }\end{array}$ & Decrease anxiety \\
\hline
\end{tabular}

Table 1 represent the application of aroma massage in medicine, Table 2, represent the application of massage by some illness, and Table 3 side effects from massage.

Table 2: Effect of massage on some illnesses.

\begin{tabular}{|c|c|c|}
\hline Illness & Application & Effect \\
\hline Stroke [18] & $\begin{array}{l}\text { Special in spastic } \\
\text { stage }\end{array}$ & Decrease spasticity \\
\hline $\begin{array}{c}\text { Parkinson disease } \\
\text { [19] }\end{array}$ & $\begin{array}{c}\text { Special area of } \\
\text { dominant muscles and } \\
\text { back }\end{array}$ & $\begin{array}{c}\text { Decrease spasticity } \\
\text { and anxiety, increase } \\
\text { joint mobility, proved } \\
\text { by decrease a cortizol } \\
\text { level in urine. }\end{array}$ \\
\hline $\begin{array}{l}\text { Peripheral nerve palsy } \\
\qquad[20]\end{array}$ & $\begin{array}{l}\text { In muscles area of } \\
\text { innervations }\end{array}$ & $\begin{array}{l}\text { Increase tonus, power, } \\
\text { circulation }\end{array}$ \\
\hline $\begin{array}{l}\text { Post-surgery limbs } \\
\text { condition [21] }\end{array}$ & $\begin{array}{l}\text { Like a lymph drainage } \\
\text { in each area }\end{array}$ & Decrease swelling, \\
\hline Spinal cord lesion [22] & $\begin{array}{c}\text { Like a lymph drainage } \\
\text { in each area, and } \\
\text { Special in spastic } \\
\text { stage, }\end{array}$ & $\begin{array}{c}\text { Decrease spasticity } \\
\text { and immobility } \\
\text { swelling }\end{array}$ \\
\hline $\begin{array}{c}\text { Patient in Coma } \\
\text { condition, [23] } \\
\text { Intensive care unit } \\
\text { [24] }\end{array}$ & $\begin{array}{c}\text { Aroma massage } \\
\text { in back, shoulder, } \\
\text { gluteus, hand and foot }\end{array}$ & $\begin{array}{l}\text { Outside stimulation } \\
\text { of brain, during } \\
\text { proprioception } \\
\text { and exteroception, } \\
\text { decrease pain }\end{array}$ \\
\hline Soft tissue lesions [25] & $\begin{array}{l}\text { In sub-acute stage, } \\
\text { from down to up, }\end{array}$ & $\begin{array}{l}\text { Reduction of swelling, } \\
\text { prevention of fibrosis. }\end{array}$ \\
\hline $\begin{array}{l}\text { Palliative care patients } \\
\qquad[26]\end{array}$ & $\begin{array}{l}\text { In pain full area, } \\
\text { before sleep, }\end{array}$ & $\begin{array}{c}\text { Better quality of } \\
\text { life, decrease pain, } \\
\text { depression, insomnia }\end{array}$ \\
\hline
\end{tabular}

Table 3: Side effects of massage by some illnesses.

\begin{tabular}{|c|c|c|}
\hline Illness & Application & Negative effect \\
\hline $\begin{array}{c}\text { Myositis ossificans } \\
\text { [27] }\end{array}$ & $\begin{array}{l}\text { On serratus anterior } \\
\text { muscles }\end{array}$ & Increase pain \\
\hline $\begin{array}{l}\text { Fracture of back bone } \\
{[28]}\end{array}$ & Massage of low back & $\begin{array}{l}\text { Fracture of vertebral } \\
\text { pedicle }\end{array}$ \\
\hline $\begin{array}{l}\text { Neck massage by } \\
\text { arteriosclerotic } \\
\text { carotid vessels, } \\
\text { Vertebral artery } \\
\text { dissection [29] }\end{array}$ & $\begin{array}{l}\text { Massage of lateral and } \\
\text { frontal part of neck }\end{array}$ & $\begin{array}{c}\text { Vertigo, } \\
\text { thromboembolism, }\end{array}$ \\
\hline $\begin{array}{l}\text { Acute stage of injury } \\
{[30]}\end{array}$ & $\begin{array}{c}\text { Area of injury is too } \\
\text { pain full }\end{array}$ & thromboembolism, \\
\hline $\begin{array}{l}\text { Neck massage with } \\
\text { manipulation [31] }\end{array}$ & On neck vertebra & $\begin{array}{l}\text { Cervical epidural } \\
\text { hematoma }\end{array}$ \\
\hline
\end{tabular}

\section{Discussion}

Since ancient times, massage therapy has been used to promote healing by people of all backgrounds and cultures [32]. In the context of the White Book of Physical and Rehabilitation Medicine (PRM) in Europe, is noted that massage is one of physical agents used in treatment of people with many illnesses [33].This finding has the importance of recognizing the massage as a scientific method for the treatment of multiple diseases. Traditional median and masses are applied in more pain conditions in patients with malignant disease, on palliative care, and are consistently standardized protocols for the treatment of persons with pain [34,35]. The low coat of pain is a common phenomenon in the doctoral practice, and the reason for the absence of work among the employees [36]. The symptoms of pain can be alleviated with appropriate mass and 
inhibitory techniques for the pain in the subcutaneous and chronic stage. Massage applied as traditional Tuina massage had an effect in children with scoliosis and can prevent the progression of scoliosis [37]. Massage is one of treatment of central spascity by patient with cerebral palsy [38], Multiple sclerosis [39], Parkinson disease [40] and after Stroke [41] increasing quality of life.

Massage is not safe for all conditions, and medical staff must know it possibilities of complications, like fracture in osteoporotic spine, jugular vein thrombosis and risk of thrombosis by patients with vein vessels insufficiency $[42,43]$

\section{Conclusion}

Massage is an first form of all therapy, it is essential for child after born, has long ancient history, but it has his place in modern physical medicine, proved by science. Massage has many positive health effects, but medical staff and massage practioners must be careful and to expect some complications specially in area of osteoporotic bones and vessels.

\section{Acknowledgements}

Authors are Acknowledgement to Prof.BorisAngelkov, President of TIC, Bitola, for all support in personal and science work.

\section{Conflict of Interest}

Authors Declare, that they have not any conflict of interest.

\section{References}

1. Shoghi M, Sohrabi S, Rasouli M (2018) The Effects of Massage by Mothers on Mother-Infant Attachment. Altern Ther Health Med 24(3): 34-39.

2. Hernandez Reif M, Field T, Ironson G,Vera Y, Hurley J, et al. (2005) Natural killer cells and lymphocytes increase in women with breast cancer following massage therapy. Int J Neurosci 115(4): 495-510.

3. Ironson G, Field T, Scafidi F, Hashimoto M, Kumar M, et al. (1996) Massage therapy is associated with enhancement of the immune system's cytotoxic capacity. Int J Neurosci 84(1-4): 205-217.

4. Calvert R (2002) The History of Massage: An Illustrated Survey from Around the World.

5. JH Kellogg (2002) The art of massage. p: 9.

6. Robert Noah Calvert (2003) The History of Massage p: 35.

7. Alan Steinfeld (2003) Careers in Alternative Medicine p: 48

8. Claire Thomas (1995) Bodywork: What Type of Massage to Get and How to Make the Most of It. William Morrow and Co. pp. 40-56.

9. Iorio Silvia, Gazzaniga Valentina, Marinozzi Silvia (2018) Healing bodies: the ancient origins of massages and Roman practices. Medicina Historica 2(2): 58-62.

10. Calvert Robert Noah (2013) Swedish Massage. Massage Magazine.

11. (2008) A Meta-Analysis of Massage Therapy Research (PDF). Psychological Bulletin.

12. Ramova PE, Angelovska B, Stojanovska H, Sofronijevska V (2018) Massage like a therapy.

13. Taylor SL, Herman PM, Marshall NJ, Zeng Q, Yuan A, et al. (2018) Use of Complementary and Integrated Health: A Retrospective Analysis of U.S. Veterans with Chronic Musculoskeletal Pain Natio nally. J Altern Complement Med 25(1): 32-39.

14. Nasiri A, Mahmodi MA (2018) Aromatherapy massage with lavender essential oil and the prevention of disability in ADL in patients with osteoarthritis of the knee: A randomized controlled clinical trial. Complement Ther Clin Pract 116-121.
15. De Oliveira FR, Visnardi Gonçalves LC, Borghi F, et al. (2018) Massage therapy in cortisol circadian rhythm, pain intensity, perceived stress index and quality of life of fibromyalgia syndrome patients. Complement Ther Clin Pract 85-90.

16. Domingos Tda S, Braga EM (2015) Massage with aromatherapy: effectiveness on anxiety of users with personality disorders in psychiatric hospitalization. Rev Esc Enferm USP 49(3): 450-456.

17.Xiong M, Li Y, Tang P, Cao M, Ni J, et al. (2018) Effectiveness of Aromatherapy Massage and Inhalation on Symptoms of Depression in Chinese Community-Dwelling Older Adults.J Altern Complement Med 24(7): 717-724.

18. Komori T, Kageyama M, Tamura Y, Yuki Tateishi, Takashi Iwasa (2018) Anti-stress effects of simplified aroma hand massage. MentIlln 10(1): 7619 .

19. Wu J, Wang Y, Wang Z (2017) The effectiveness of massage and touch on behavioural and psychological symptoms of dementia: A quantitative systematic review and meta-analysis. J Adv Nurs 73(10): 2283-2295.

20. Kadir AA, Hamid AH, Mohammad M (2015) Pattern of complementary and alternative medicine use among Malaysian stroke survivors: A hospital-based prospective study. J Tradit Complement Med 5(3):157160 .

21. Donoyama N, Suoh S, Ohkoshi N (2014) Effectiveness of Anma massage therapy in alleviating physical symptoms in outpatients withParkinson's disease: a before-after study.ComplementTher Clin Pract 20(4): 251-261.

22. Druschky KF (1979) Conservative treatment of peripheral nerve lesions. Fortschr Med 97(27): 1185-1190.

23. Chen Q Huang S, Chen X, Feng L, Zhu X (2016) Clinical efficacy of multi-pattern detumescence after total knee arthroplasty treated with acupoint massage and mild moxibustion]. Zhongguo Zhen Jiu 36(5): 471-475.

24. Norrbrink Budh C, Lundeberg T (2004) Non-pharmacological painrelieving therapies in individuals with spinal cord injury: a patient perspective. Complement Ther Med 12(4): 189-197.

25. Hatefi M, Jaafarpour M, Khani A (2015) The Effect of WholeBody Massage on the Process and Physiological Outcome of Trauma ICU Patients: A Double-Blind Randomized Clinical Trial. J Clin Diagn Res $9(6): 5-8$.

26. Papathanassoglou EDE, Hadjibalassi M, Miltiadous P, Lambrinou E, Papastavrou E, et al. (2018)Effects of an Integrative Nursing Intervention on Pain in Critically Ill Patients: A Pilot Clinical Trial. Am J Crit Care 27(3): 172-185.

27. Brummitt J (2008) The role of massage in sports performance and rehabilitation: current evidence and future direction. N Am J Sports Phys Ther 3(1): 7-21.

28. Coelho A, Parola V, Cardoso D,Bravo ME, Apóstolo J (2017) Use of nonpharmacological interventions for comforting patients in palliative care: a scoping review. JBI Database System Rev Implement Rep 15(7): 18671904.

29. Wei J, Jia Y, Liang B (2015) Myositis ossificans of the serratus anterior as a rare complication of massage: a case report. J Med Case Rep 9: 143.

30. Doi Guo Z, Chen W, Su Y,Zhang Y (2013) Isolated unilateral vertebral pedicle fracture caused by a back massage in an elderly patient: a case report and literature review. Eur J Orthop Surg Traumatol Suppl 2: S149153.

31. Dutta G, Jagetia A, Srivastava AK, Singh D, Singh H, et al. (2018) "Crick" in Neck Followed by Massage Led to Stroke: Uncommon Case of Vertebral Artery Dissection. World Neurosurg 115: 41-43.

32. Behera C, Devassy S, Mridha AR, Chauhan M, Gupta SK (2018) Leg massage by mother resulting in fatal pulmonary thromboembolism. Med Leg J 86(3): 146-150.

33. Ryu JI, Han MH, Kim JM, Kim CH, Cheong JH (2018) Cervical Epidural Hematoma That Induced Sudden Paraparesis After Cervical Spine Massage: Case Report and Literature Review. World Neurosurg 112: $217-220$. 
34. Westman KF, Blaisdell C (2016) Many Benefits, Little Risk: The Use of Massage in Nursing Practice. Am J Nurs 116(1): 34-39.

35. (2018) European Physical and Rehabilitation Medicine Bodies Alliance White Book on Physical and Rehabilitation Medicine (PRM) in Europe. Chapter 4, History of the specialty: where PRM comes from. Eur J Phys Rehabil Med 54(2):186-197.

36. Shin ES, Seo KH, Lee SH, Jung YM, Kim MJ, et al. (2016) Massage with or without aromatherapy for symptom relief in people with cancer (6).

37. Greenlee H, DuPont-Reyes MJ, Balneaves LG, Carlson LE, Cohen MR, et al. (2017) Clinical practice guidelines on the evidence-based use of integrative therapies during and after breast cancer treatment. .CA Cancer J Clin 67(3): 194-232.

38. Brosseau L, Wells GA, Poitras S, Tugwell P, Casimiro L, et al. (2012) Ottawa Panel evidence-based clinical practice guidelines on therapeutic massage for low back pain. J Bodyw Mov Ther 16(4): 424455.

39. Wei H, Xu J, Jiang Z, Ye Shuliang, Song Hongquan, et al. (2015) Effect of a Traditional Chinese Medicine combined therapy on adolescent idiopathic scoliosis: a randomized controlled trial. J Tradit Chin Med 35(5): 514-519.
40. Özkan F, Zincir H (2017) The effect of reflexology upon spasticity and function among children with cerebral palsy who received physiotherapy: Three group randomised trial. Appl Nurs Res 36: 128-134.

41. Backus D, Manella C, Bender A, Mark Sweatman (2016) Impact of Massage Therapy on Fatigue, Pain, and Spasticity in People with Multiple Sclerosis: a Pilot Study. Int J Ther Massage Bodywork 9(4): 4-13.

42. Miyahara Y, Jitkritsadakul O, Sringean J, Aungkab N, Khongprasert S,et al.(2018): Can therapeutic Thai massage improve upper limb muscle strength in Parkinson's disease? An objective randomized-controlled trial. J Tradit Complement Med 8(2): 261-266.

43. Thanakiatpinyo T, Suwannatrai S, Suwannatrai U, Khumkaew P, Wiwattamongkol D, et al. (2014): The efficacy of traditional Thai massage in decreasing spasticity in elderly stroke patients. Clin Interv Aging 9: 1311-1319.

44. Raju S, Byrne J (2017) External jugular vein thrombosis secondary to deep tissue neck massage. J Vasc Surg Cases Innov Tech 3(3): 146-148.

45. Guo Z, Chen W, Su Y, Zhang Y (2013) Isolated unilateral vertebral pedicle fracture caused by a back massage in an elderly patient: a case report and literature review. Eur J Orthop Surg Traumatol Suppl 2: S149-153. 